\title{
SHIP EMISSION ESTIMATION FOR IZMIR AND MERSIN INTERNATIONAL PORTS - TURKEY
}

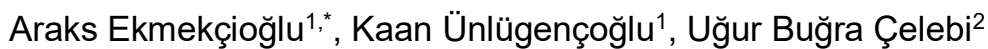

\begin{abstract}
Approximately $90 \%$ of the world trade is done by sea trade. The world maritime trade fleet is also increasing every year. Since ships use fossil fuels, they contribute to global climate change. It is very important for the environment and human health to calculate emissions in the port areas where ships do cargo operations. In this study, emissions analysis of the two important ports of Turkey's is performed with using the bottom-up calculation method. In addition, hotelling periods of the vessels are monitored for both ports for one year period. As a result, total Nitrogen Oxide $\left(\mathrm{NO}_{x}\right)$, Sulphur Dioxide $\left(\mathrm{SO}_{2}\right)$, Carbon Dioxide $\left(\mathrm{CO}_{2}\right)$, Volatile Organic Compounds (VOC), Particulate Matter (PM) and Carbon Monoxide (CO) emissions of İzmir Port are calculated as 900 tons/year, 589 tons/year, 45320.5 tons/year, 49.7 tons/year, 77.7 tons/year and 36.9 tons/year, respectively. Moreover, total $\mathrm{NO}_{x}, \mathrm{SO}_{2}, \mathrm{CO}_{2}$, VOC, $\mathrm{PM}$ and $\mathrm{CO}$ emissions of Mersin Port are calculated as 1998 tons/year, 1339 tons/year, 102330 tons/year, 114.5 tons/year, 178.5 tons/year and 82.5 tons/year, respectively. The amount of emissions of Mersin port, which has a higher number of movements, was higher than that of İzmir port.
\end{abstract}

\section{Keywords: Shipping Emissions, Ports, Global Warming, Green Shipping}

\section{INTRODUCTION}

In recent years, emissions from ships have increased due to increased ship activities, intensification of port traffic, and preference of high-powered and heavy-fueled engines. Due to the effects of emissions on global warming and air pollution, monitoring and reduction of shipping emissions have become a necessity. Therefore, International Maritime Organization (IMO) imposes sanctions on ships within the scope of emission reduction preventions. Especially port cities are exposed to serious air pollution due to exhaust emissions from ships berthing to the port. Recently, new regulations have been established by the IMO and the European Union (EU) regarding to the reduction of emissions from ships. Within the framework of these regulations, monitoring of shipping emissions has become more important. In this study, Nitrogen Oxide $\left(\mathrm{NO}_{\mathrm{x}}\right)$, Sulphur Dioxide $\left(\mathrm{SO}_{2}\right)$, Carbon Dioxide $\left(\mathrm{CO}_{2}\right)$, Volatile Organic Compounds (VOC), Particulate Matter (PM) and Carbon Monoxide (CO) emissions are theoretically calculated with developed web-based emission calculation software [1][2] by taking into account the type, construction year, gross tonnage (GRT), main engine power, revolution and auxiliary engine power, the number of arrivals and the time of cruising, manoeuvring and hotelling of ships arriving to İzmir and Mersin ports for 1 year period.

When the studies on this subject are examined in the literature, R.A.O. Nunes et al. [3] calculated emissions from ships arriving to Portugal's four main ports (Setubal, Leixo, Sines, Viana do Castelo) numerically in three modes of operation (manoeuvring, hotelling and during cruising). Power of the auxiliary engines are obtained from Trozzi [4] and the average speeds of ships are obtained from Entec [5]. Tzannos [6] calculated $\mathrm{NO}_{\mathrm{x}}, \mathrm{SO}_{2}$ and PM2.5 emissions from passenger ships berthed at Piraeus Port of Greece between 2008-2009. As a result, total annual emissions were calculated as 2600 tons. Knezevic et al. [7] estimated the exhaust emissions from ships arriving to the port of Zadar in Croatia over a period of one year using the bottom-up method. They calculated the amount of $\mathrm{NO} x$, Sulphur Oxide $\left(\mathrm{SO}_{\mathrm{x}}\right), \mathrm{PM}, \mathrm{VOC}$ and $\mathrm{CO}_{2}$ released and concluded that $80 \%$ of the total emissions released at the port caused by passenger ships due to the growth of cruise ship tourism. In their study, Coello et al. [8] calculated emissions from fishing vessels in the United Kingdom (UK) using Automatic Identification System (AIS) data. It is assumed that all fishing vessels have been using diesel oil. They compared

This paper was recommended for publication in revised form by Regional Editor Bekir Şener

${ }^{1}$ Department of Marine Engineering, Yildiz Technical University, Istanbul, Turkey

2 Department of Naval Arch. \& Marine Engineering, Yildiz Technical University, Istanbul, Turkey

*E-mail address: araks@yildiz.edu.tr

Orcid id: 0000-0002-4821-0272, 0000-0002-3092-148X, 0000-0002-2658-1291

Manuscript Received 3 October 2019, Accepted 3 November 2019 
fuel-based calculation with activity-based calculation and stated that activity-based calculations are more accurate than fuel-based calculation due to using real AIS data. In the calculations of Olukanni and Esu [9], Chang et al's [10] study in 2013 was used, it was concluded that the most $\mathrm{CO}_{2}$ released during anchorage and the entry of breakwaters, and 5\% of the total emissions at the port were released. In their study, Ledoux et al. [11] have measured exhaust emissions at the port of Calais in Northern France for a period of 3 months and analyzed the internal effects of emissions. They concluded that the effect of maritime transport at the port of Calais on average concentrations is $51 \%$ for $\mathrm{SO}_{2}, 35 \%$ for $\mathrm{NO}, 15 \%$ for $\mathrm{NO}_{2}$ and $2 \%$ for PM10. Chu-Van et al. [12] made measurements on a dry cargo ship at the ports of Newcastle and Gladstone. Separate measurements were taken from the main engine and exhaust outlets and emissions were calculated at berth, manoeuvring and cruising at sea position. $\mathrm{CO}, \mathrm{CO}_{2}, \mathrm{SO}_{2}, \mathrm{NO}_{\mathrm{x}}$, Hydrocarbon ( $\mathrm{HC}$ ), $\mathrm{PM}$ emissions were examined, the results were compared with other studies in the literature and the difference in the results obtained was emphasized. Cheng and Haibo [13] examined air pollutants sourced from auxiliary engines of ships in Chinese ports, compared ships that using shore power and ships that do not use shore power in port. In their studies examining emissions from electricity generation in China, they concluded that the annual $\mathrm{SO}_{2}, \mathrm{NO}_{\mathrm{x}}$ and $\mathrm{CO}_{2}$ emissions would decrease by 16 thousand tons, 128 thousand tons and 1435 thousand tons, respectively, by using shore power in ships at ports. Sun et al. [14] calculated the exhaust emissions of ships arriving to China's Quindao port in 5 operating modes (cruising, preparing, decelerating, manoeuvring, and hotelling). As a result, they compared the values of $\mathrm{HC}, \mathrm{CO}_{2}, \mathrm{SO}_{2}$ and PM with the three ports in the Emission Control Area (ECA) region and emphasized the necessity of taking precautions. In their study, Chen et al. [15] estimated the exhaust emission values of 8690 vessels arriving at Tiajin port during 2014 and compared them with emissions from other ports in China. They compared their own emission estimation method with other methods. Deniz and Durmuşoğlu [16] forecasted exhaust gas emissions from ships in the Sea of Marmara and the Turkish Straits, and compared the results with the other transportation way in Turkey. The authors considered some parameters such as the main engine types, fuel types, operation types, navigation times and speeds of vessels in calculation methods. Schembari et al. [17] examined the change in the concentrations of $\mathrm{SO}_{2}, \mathrm{NO}_{\mathrm{x}}$ and $\mathrm{BC}$ in different European ports by a European Union rule that entered into force in 2010, with measurements made at a measurement station placed on a cruise ship called Costa Pacifica. As a result, they emphasized the effect of low sulfur fuel use on air pollution and environmental factors. Consequently, they emphasized the effect of low sulfur fuel usage on air pollution and environmental factors. In an analysis by Zetterdahl et al. [18] on a ship in two stages, the ship used heavy fuel oil in the first stage and low sulfur fuel in the second stage. As a result, $\mathrm{SO} 2$ emissions and PM values were found to be decreased in low sulfur fuel usage. In their study, Tichavska et al. [19] calculated and compared the exhaust emissions from ships in ports which were subject to 3 different regulatory applications (EU, Sulphur Emission Control Area (SECA) and non EU / non SECA) for 12 months, according to Ship Traffic Emission Assessment Model (STEAM) and AIS data. In their study, Piris et al. [20] measured the reduction in $\mathrm{CO}_{2}$ emissions of merchant ships for the first time as a result of replacing traditional mooring systems with new automatic mooring systems. Using the ENTEC method [21], they have concluded that $\mathrm{CO}_{2}$ emissions are reduced by $76.78 \%$ compared to traditional mooring systems. Bilgili and Çelebi [22] investigated the airborne emissions of nine bulk carrier ships by means of block coefficient and deadweight characteristics during predesign as a result, emissions were calculated with three different methods and some equations was obtained with regards to regression analysis. Ünlügençoğlu [2] developed the web-based data collection software which monitor emissions from ships and performed for Ambarlı Port, Turkey.

In this study, Izmir and Mersin ports were monitored for a period of one year between 2017-2018, $\mathrm{NO}_{\mathrm{x}}$, $\mathrm{SO}_{2}, \mathrm{CO}_{2}$, VOC, $\mathrm{PM}$ and $\mathrm{CO}$ emissions from ships arriving at the ports were calculated numerically in terms of cruising, manoeuvring and hotelling positions. In the calculations, the actual data of the ships (power \& rpm of main engine, power of auxiliary engine, year of construction, gross tonnage, flag, number of arrivals, cruising, manoeuvring and hotelling) were used. The calculated emissions were classified according to ship types. The ages of the ships arriving at the port in the same period and the average hotelling period in the port were determined. A comparison was made between İzmir and Mersin port and other existing studies.

\section{MATERIAL AND METHOD}

İzmir Port is located on the west coast of the Aegean Sea in the Alsancak area of the Gulf of Izmir. The port has a large agricultural and industrial hinterland. İzmir Port, which is the agricultural and industrial port of the Aegean region, also plays a vital role in the export of the country. The port serves all kinds of cargo and is 
connected to the railway and highway network. Izmir Port serves mainly cargo and cruise passenger ships. 500,000 passengers, 1 million TEU containers and 10 million tons of cargo are handled annually. The Port employs 800 people and has an annual average turnover of 100 million usd [23].

Figure 1 shows the top view of the port of Izmir. In the study, the distance between A-B was accepted cruising, the distance between $\mathrm{B}-\mathrm{C}$ was accepted manoeuvring and the $\mathrm{C}$-point was accepted as a hotelling (port). Distance A-B is $16.7 \mathrm{~km}$, the distance between B-C is $5.5 \mathrm{~km}$. Point B is the point of taking of the pilot on the ship who helps berthing and departure. The start of the maneuver was accepted as the moment the pilot was taken. The cruising speed of the ships is accepted as 18 knots and the manoeuvring speed is 3 knots. These points, distances and speeds were determined according to the information obtained from the oceangoing captains who worked at the relevant port.

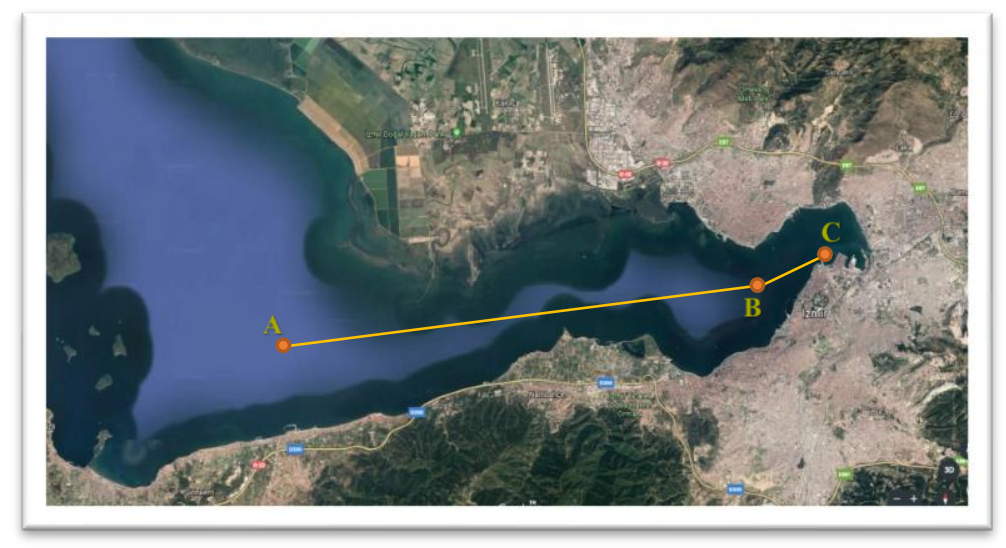

Figure 1. İzmir Port

Mersin International Port, which is 112 hectares in size, is not only one of the most important ports of Turkey, at the same time is one of the most important ports in the eastern Mediterranean with advantages of capacity, geographical location and wide hinterland. The port is connected to the domestic lines and the countries of the Middle East by highways, airways and railways and is ideally located for transit cargoes to Central Asia and the Middle East. The port serves container, general cargo, roro, dry bulk cargo, liquid bulk cargo ships. Mersin International Port, which has 21 berths, provides loading/unloading services to nearly 30 ships at the same time. The port handles over 30 million tons of cargo per year [24]. İzmir Port.

Figure 2 shows the top view of the port of Mersin. In the study, the distances were accepted as same as

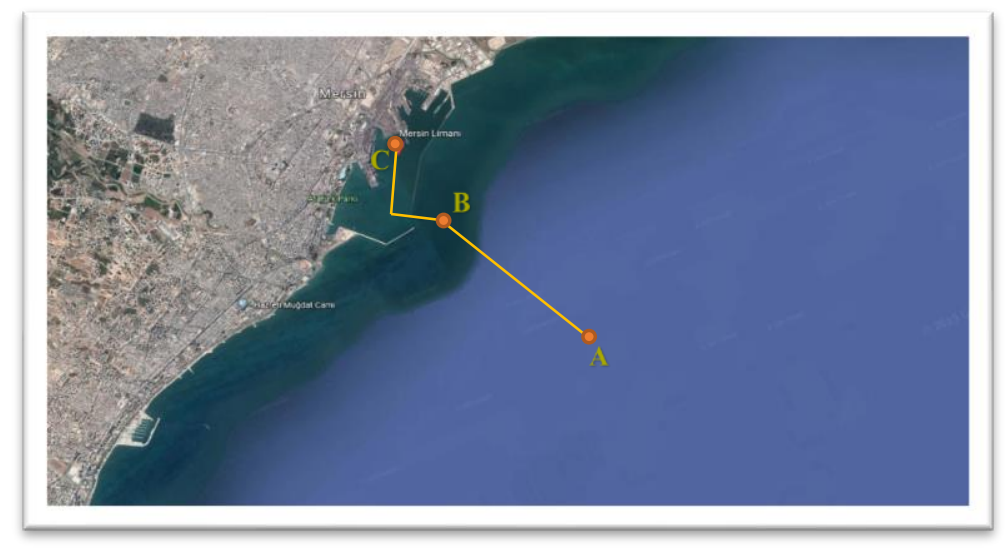

Figure 2. Mersin Port

Additionally, the types of ships arriving at Izmir and Mersin Ports on the dates indicated are shown in Figure 3 . 
Journal of Thermal Engineering, Research Article, Vol. 5, No. 6, Special Issue 10, pp. 184-195, December, 2019
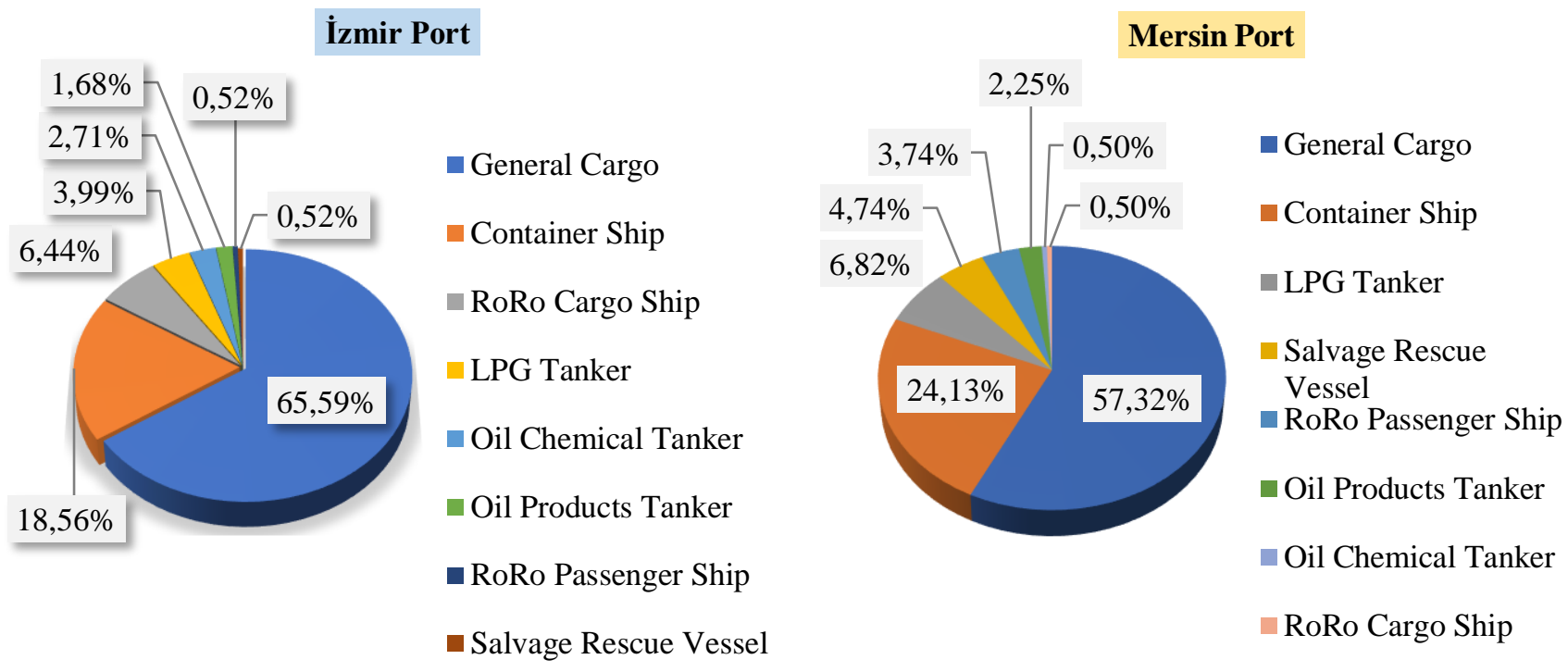

Figure 3. Ship types arriving at Izmir and Mersin Ports between 01.09.2017 and 01.09.2018

Table 1 shows the classification of 776 different ships arriving at Izmir port in the date range according to their flags.

Table 1. Flags of the ships arriving at Izmir Port between 01.09.2017 - 01.09.2018

\begin{tabular}{|c|c|c|c|c|c|c|c|c|}
\hline Flags & Number & Movement & Flags & Number & Movement & Flags & Number & Movement \\
\hline Turkey & 127 & 660 & Bahamas & 9 & 14 & Norway & 2 & 2 \\
\hline Panama & 98 & 212 & Belize & 8 & 9 & $\begin{array}{c}\text { Saint Kitts \& } \\
\text { Nevis }\end{array}$ & 2 & 3 \\
\hline Russia & 70 & 88 & Portugal & 7 & 23 & Saudi Arabia & 2 & 2 \\
\hline Malta & 60 & 218 & Azerbaijan & 6 & 8 & Usa & 2 & 2 \\
\hline Antigua & 58 & 91 & \begin{tabular}{|l|} 
England \\
\end{tabular} & 6 & 8 & Albania & 1 & 1 \\
\hline Liberia & 56 & 188 & Gibraltar & 6 & 8 & Algeria & 1 & 1 \\
\hline Netherlands & 39 & 53 & $\begin{array}{l}\text { Hong } \\
\text { Kong }\end{array}$ & 6 & 35 & Barbados & 1 & 1 \\
\hline Cook Islands & 27 & 35 & $\begin{array}{l}\text { Sierra } \\
\text { Leone }\end{array}$ & 6 & 10 & Bermuda & 1 & 8 \\
\hline Marshall Isl. & 20 & 51 & $\begin{array}{c}\text { Saint } \\
\text { Vincent } \\
\text { Gr. }\end{array}$ & 4 & 4 & Bulgaria & 1 & 1 \\
\hline Moldova & 20 & 53 & Sweden & 4 & 5 & Cayman Isl. & 1 & 1 \\
\hline Comoros & 18 & 37 & Denmark & 3 & 3 & China & 1 & 1 \\
\hline Vanuatu & 16 & 19 & Egypt & 3 & 7 & Jamaica & 1 & 3 \\
\hline Singapore & 15 & 18 & Germany & 3 & 13 & Luxemburg & 1 & 2 \\
\hline Tanzania & 15 & 23 & Greece & 3 & 6 & South Korea & 1 & 1 \\
\hline Togo & 14 & 23 & $\begin{array}{c}\text { Isle Of } \\
\text { Man }\end{array}$ & 3 & 3 & Spain & 1 & 1 \\
\hline Italy & 10 & 89 & Lebanon & 3 & 4 & Sri Lanka & 1 & 1 \\
\hline Palau & 10 & 14 & Ukraine & 3 & 5 & & & \\
\hline
\end{tabular}

Table 2 shows the classification of 1202 different ships arriving at Mersin Port in the date range according to their flags. 
Journal of Thermal Engineering, Research Article, Vol. 5, No. 6, Special Issue 10, pp. 184-195, December, 2019

Table 2. Flags of the ships arriving at Mersin Port between 01.09.2017 - 01.09.2018

\begin{tabular}{|c|c|c|c|c|c|c|c|c|}
\hline Flags & Numbel & Govement & Flags & Numbe & Iovement & Flags & Number & rMovement \\
\hline Panama & 176 & 394 & Tanzania & 15 & 24 & China & 2 & 7 \\
\hline Turkey & 123 & 864 & Moldova & 13 & 52 & Israel & 2 & 21 \\
\hline Malta & 113 & 304 & Denmark & 11 & 30 & Norway & 2 & 2 \\
\hline Liberia & 108 & 368 & Greece & 11 & 23 & $\begin{array}{c}\text { Saint Vincent } \\
\text { Gr. }\end{array}$ & 2 & 2 \\
\hline Marshall Isl. & 82 & 225 & Vanuatu & 11 & 14 & Switzerland & 2 & 2 \\
\hline Russia & 50 & 63 & Cyprus (TRNC) & 10 & 613 & Algeria & 1 & 1 \\
\hline Netherlands & 47 & 51 & Palau & 9 & 30 & Bahrain & 1 & 7 \\
\hline Hong Kong & 40 & 107 & $\begin{array}{c}\text { Saint Kitts \& } \\
\text { Nevis }\end{array}$ & 9 & 76 & Bermuda & 1 & 8 \\
\hline Antigua & 38 & 51 & Germany & 7 & 30 & British Indian & 1 & 2 \\
\hline Togo & 38 & 115 & Barbados & 5 & 7 & Cayman Isl. & 1 & 1 \\
\hline Singapore & 35 & 83 & Japan & 5 & 6 & Croatia & 1 & 1 \\
\hline Bahamas & 28 & 50 & Saudi Arabia & 5 & 5 & Curaçao & 1 & 2 \\
\hline Italy & 25 & 54 & Azerbaijan & 4 & 5 & Ireland & 1 & 1 \\
\hline Belize & 23 & 93 & Egypt & 4 & 12 & Isle of man & 1 & 8 \\
\hline Cook Islands & 23 & 40 & Gibraltar & 4 & 4 & Morocco & 1 & 7 \\
\hline Sierra Leone & 23 & 42 & Sweden & 4 & 5 & Philippines & 1 & 4 \\
\hline Portugal & 20 & 122 & Luxemburg & 3 & 18 & Seychelles & 1 & 1 \\
\hline England & 17 & 47 & Tuvalu & 3 & 3 & Spain & 1 & 2 \\
\hline Comoros & 15 & 17 & Usa & 3 & 56 & Thailand & 1 & 1 \\
\hline Lebanon & 15 & 29 & Belgium & 2 & 2 & Ukraine & 1 & 1 \\
\hline
\end{tabular}

\section{METHODOLOGY}

There are two methods in the literature in order to calculate emissions from ships numerically. One method is bottom-up methodology based on the activity and movement of ships. In this method, calculations are done by formulas based on main engine auxiliary engine powers, rpm, hotelling time, ect. The other method is the top-down method based on a ship's consumption of fuel oil For estimating emissions this method uses the fuel consumption quantities and corresponding emission factors of the fuel [25].

Bottom-up method is used in this study, the emission factors of the ships are calculated by applying emission factors according to the 3 operating modes of ships (cruising, manoeuvring and hotelling). Emission factors were used depending on the operating modes, rpm of the main engine and the type of fuel used [21]. In order to find the total exhaust gas emissions emitted from the ships arriving at the port, the amounts of the exhaust gases emitted by the vessels during their operation modes of cruising, manoeuvring and hotelling were calculated. The calculations were made with the help of real data such as main engine power and rpm, auxiliary engine power, types of fuel consumed, cruising, manoeuvring and hotelling without using any estimation methodology in the literature. 2068 movements of 776 different ships that arrived to Izmir Port and 4215 movements of 1202 different ships that arrived to Mersin Port were followed in a period of one year, between 01.09.2017 and 01.09.2018. $\mathrm{NO}_{x}, \mathrm{SO}_{2}, \mathrm{CO}_{2}, \mathrm{VOC}, \mathrm{PM}$ and $\mathrm{CO}$ emissions from main and auxiliary engines were calculated for both ports.

The formula given in Equation 1 was used to calculate the exhaust gas emissions generated by the ships arriving to İzmir and Mersin Ports in cruising, manoeuvring and hotelling modes [21].

$$
E(g)=T(h) \times\left[\begin{array}{l}
\left(M E(k W) \times L F_{M E}(\%)\right) \times E F(g / k W h) \\
+\left(A E(k W) \times L F_{A E}(\%)\right) \times E F(g / k W h)
\end{array}\right]
$$


Where; E, emissions (g) generated in the related operating mode (cruising, manoeuvring and hotelling); $\mathrm{T}(\mathrm{h})$, time spent in the related operating mode; $\mathrm{ME}$, main engine power $(\mathrm{kW})$; The $\mathrm{LF}_{\mathrm{ME}}$ represents the main engine load factor $(\%)$ in the related operating mode; $\mathrm{AE}$, the power of auxiliary engine $(\mathrm{kW}) ; \mathrm{LF}_{\mathrm{AE}}$ is the load factor $(\%)$ of the auxiliary engine in the related operating mode; EF refers to emission factors $(\mathrm{g} / \mathrm{kWh})$ for each type of ship, depending on the type of fuel used in the related operation mode and main engine type.

The main and auxiliary engine power of the vessels required for the related calculation method and the hotelling period of the vessels in the port were determined by monitoring 772 different ships arriving to İzmir Port and 1202 different ships arriving to Mersin Port on the specified dates.

The cruising time for İzmir and Mersin Ports was calculated with dividing the cruising distance made at berthing and departure $(2 \times 16.7 \mathrm{~km})$ by cruising speed $(18$ knots, $33.336 \mathrm{~km})$ and found 1 hour $(\mathrm{h})$. The maneuvering time for İzmir and Mersin Ports was calculated with dividing the maneuvering distance made at berthing and departure $(2 \times 5.5 \mathrm{~km})$ by the maneuver speed $(3 \mathrm{knots}, 5.556 \mathrm{~km})$ and found $2 \mathrm{~h}$. Hotelling times were obtained by monitoring the ports.

In addition, it was assumed that 2 auxiliary engines were loaded in cruising and manoeuvring and one auxiliary engine in port [2]. Confirmation was received from the captains of the oceangoing ships that worked for the relevant ports for these acceptances. Exhaust gas emissions from each ship were calculated with the developed web-based "Emission Calculation Software" [1][2].

The engine types according to the main engine rpm are shown in Table 3.

Table 3. Main engine types and revolutions [21]

\begin{tabular}{|c|c|c|}
\hline Main Engine Revolution & Speed (n), rpm & Main Engine Specification \\
\hline Slow Speed Diesel - SSD & $\mathrm{n} \leq 300$ & Two Stroke Diesel Engine \\
\hline Medium Speed Diesel - MSD & $300<\mathrm{n} \leq 1000$ & Four Stroke Diesel Engine \\
\hline High Speed Diesel - HSD & $\mathrm{n}>1000$ & $\begin{array}{c}\text { Four Stroke Diesel Engine, } \\
\text { Steam \& Gas Turbine }\end{array}$ \\
\hline
\end{tabular}

In the calculations, the fuel type used for the main engine was Heavy Fuel Oil (HFO) and the fuel type used for the auxiliary engine was Marine Diesel Oil (MDO). Emission factors were determined according to the operating modes and main engine rpm. According to the type of fuel, type of main engine and ship operating modes the emission factors used in the calculation of main and auxiliary engine emissions in different operating modes for each type of ship are shown in Table 3, Table 4 and Table 5.

The emission factors in the calculation of main engine emissions for each ship type are shown in Table 4 according to the type of fuel, main engine and cruising mode of the vessel. In the table, $\mathrm{NO}_{\mathrm{x}} 1$ refers to the emission factor value for ships built before $2000, \mathrm{NO}_{\mathrm{x}} 2$ refers to the emission factor value for ships built after 2000 .

Table 4. Emission factors according to main engine type on cruising mode (g/kWh) [21]

\begin{tabular}{|c|c|c|c|c|c|c|c|c|}
\hline $\begin{array}{c}\text { Operational } \\
\text { Mode }\end{array}$ & Type & $\mathbf{N O}_{\mathbf{x}} \mathbf{1}$ & $\mathbf{N O}_{\mathbf{x}} \mathbf{2}$ & $\mathbf{S O}_{2}$ & $\mathbf{C O}_{2}$ & $\mathbf{V O C}$ & $\mathbf{P M}$ & $\mathbf{C O}$ \\
\hline Cruising & $\begin{array}{c}\text { Slow Speed - } \\
\text { SSD - (HFO) }\end{array}$ & 18.1 & 15 & 10.5 & 620 & 0.6 & 1.7 & 0.54 \\
\hline Cruising & $\begin{array}{c}\text { Medium Speed - } \\
\text { MSD - (HFO) }\end{array}$ & 14 & 11.6 & 11.5 & 677 & 0.5 & 0.8 & 0.54 \\
\hline Cruising & $\begin{array}{c}\text { High Speed - } \\
\text { HSD - (HFO) }\end{array}$ & 12.7 & 10.5 & 11.5 & 677 & 0.2 & 0.8 & 0.54 \\
\hline
\end{tabular}

For each type of ship, the emission factors used in the calculation of emissions from the auxiliary engine are shown in Table 5, depending on the type of fuel used in cruising, manoeuvring and hotelling.

Table 5. Auxiliary engine emission factors (g/kWh) [21]

\begin{tabular}{|c|c|c|c|c|c|c|c|}
\hline & $\mathbf{N O}_{\mathbf{x}} \mathbf{1}$ & $\mathbf{N O}_{\mathbf{x}} \mathbf{2}$ & $\mathbf{S O}_{2}$ & $\mathbf{C O}_{2}$ & VOC & PM & CO \\
\hline Auxiliary Engine (MDO) & 13.9 & 11.5 & 6.5 & 690 & 0.4 & 0.4 & 0.54 \\
\hline
\end{tabular}


Journal of Thermal Engineering, Research Article, Vol. 5, No. 6, Special Issue 10, pp. 184-195, December, 2019

For each type of ship, the emission factors of main engine are shown in Table 6, depending on the type of engine and fuel used in manoeuvring and hotelling modes.

Table 6. Emission factors according to main engine type in manoeuvring and hotelling (g/kWh) [21]

\begin{tabular}{|c|c|c|c|c|c|c|c|c|}
\hline Operational Mode & Type & NOx1 & $\mathbf{N O}_{\mathbf{x}}$ & $\mathbf{S O}_{2}$ & $\mathbf{C O}_{2}$ & VOC & PM & CO \\
\hline $\begin{array}{c}\text { Manoeuvring - } \\
\text { Hotelling }\end{array}$ & SSD - HFO & 14.5 & 12 & 11.6 & 682 & 1.8 & 2.4 & 0.54 \\
\hline $\begin{array}{c}\text { Manoeuvring - } \\
\text { Hotelling }\end{array}$ & MSD - HFO & 11.2 & 9.3 & 12.7 & 745 & 1.5 & 2.4 & 0.54 \\
\hline $\begin{array}{c}\text { Manoeuvring - } \\
\text { Hotelling }\end{array}$ & HSD - HFO & 10.2 & 8.5 & 12.7 & 745 & 0.6 & 2.4 & 0.54 \\
\hline
\end{tabular}

Table 7 shows the main and auxiliary engine loads in the different operating modes used in the module in the calculations made in the web-based software [20]. Main engine loads were $80 \%$ at cruising and $30 \%$ at manoeuvring. Loads of the auxiliary engines were $50 \%$ at cruising, $80 \%$ at manoeuvring and $50 \%$ at hotelling.

Table 7. Main and auxiliary engine loads in different operating modes

\begin{tabular}{|c|c|c|}
\hline $\begin{array}{c}\text { Operational } \\
\text { Mode }\end{array}$ & $\begin{array}{c}\text { Main Engine Load, } \\
\text { LF }_{\text {ME }}\end{array}$ & $\begin{array}{c}\text { Auxiliary Engine } \\
\text { Load, LF } \mathbf{F E}_{\mathbf{A E}}\end{array}$ \\
\hline Manoeuvring & 0.3 & 0.8 \\
\hline Hotelling & 0 & 0.5 \\
\hline Cruising & 0.8 & 0.5 \\
\hline
\end{tabular}

\section{RESULTS AND DISCUSSION}

$\mathrm{NO}_{x}, \mathrm{SO}_{2}, \mathrm{CO}_{2}, \mathrm{VOC}, \mathrm{PM}$ and $\mathrm{CO}$ emissions from 2068 movements of 776 different ships arriving to Izmir Port and 4215 movements of 1202 different ships arriving to Mersin Port between 01.09.2017 and 01.09.2018 were calculated. Total emissions from Izmir port are shown in Table 8 and total emissions from Mersin Port are shown in Table 9 according to the operating modes of ships. Because of the number of ship movements is higher in Mersin port, all emission values are higher than İzmir port. When the total emission amounts are analyzed, it is seen that the most emitted emission is $\mathrm{CO}_{2}$.

Table 8. Amount of total emission according to ship operating modes in Izmir Port

\begin{tabular}{|c|c|c|c|c|}
\hline \multirow{2}{*}{ Emissions } & \multicolumn{4}{|c|}{ Total Emissions, ton. $\mathbf{~}^{-1}$} \\
\cline { 2 - 5 } & Cruising & Manoeuvring & Hotelling & Total \\
\hline $\mathrm{NO}_{\mathrm{X}}$ & 316 & 244 & 340 & 900 \\
\hline $\mathrm{SO}_{2}$ & 211 & 201 & 177 & 589 \\
\hline $\mathrm{CO}_{2}$ & 12984 & 13497.5 & 18839 & 45320.5 \\
\hline $\mathrm{VOC}$ & 11.7 & 27 & 11 & 49.7 \\
\hline $\mathrm{PM}$ & 30.7 & 36 & 11 & 77.7 \\
\hline $\mathrm{CO}$ & 10.9 & 11 & 15 & 36.9 \\
\hline
\end{tabular}

Table 9. Amount of total emission according to ship operating modes in Mersin Port

\begin{tabular}{|c|c|c|c|c|}
\hline \multirow{2}{*}{ Emissions } & \multicolumn{4}{|c|}{ Total Emissions, ton. ${ }^{-1}$} \\
\cline { 2 - 5 } & Cruising & Manoeuvring & Hotelling & Total \\
\hline $\mathrm{NO}_{\mathrm{X}}$ & 717 & 560 & 721 & 1998 \\
\hline $\mathrm{SO}_{2}$ & 488 & 468 & 383 & 1339 \\
\hline $\mathrm{CO}_{2}$ & 30092 & 31623 & 40615 & 102330 \\
\hline $\mathrm{VOC}$ & 28 & 63 & 23.5 & 114.5 \\
\hline $\mathrm{PM}$ & 72 & 83 & 23.5 & 178.5 \\
\hline $\mathrm{CO}$ & 25.5 & 25 & 32 & 82.5 \\
\hline
\end{tabular}




\section{Emissions from the main engine of ships}

Between 01.09.2017 - 01.09.2018, the emissions of $\mathrm{NO}_{\mathrm{x}}, \mathrm{SO}_{2}, \mathrm{CO}_{2}, \mathrm{VOC}, \mathrm{PM}$ and $\mathrm{CO}$ from the main engine were calculated with the 2068 movements of 776 different ships arriving to Izmir Port and 4215 movements of 1202 different ships arriving to Mersin Port. Exhaust gas emissions from each ship's main engine are calculated using the web-based emission calculation software [1][2] and are shown in Table 10 according to ship operation modes. Since the main engine is only used in cruising and manoeuvring, the table shows only cruise and maneuver modes. In Mersin port, where the average age of ships and number of movements is high, total emission amounts and also unit emission (ton. $\mathrm{y}^{-1 /}$ movements) amounts are higher.

Table 10. Emissions from main engines according to operating modes in Izmir \& Mersin Port

\begin{tabular}{|c|c|c|}
\hline \multirow{2}{*}{$\begin{array}{c}\text { İmir Port } \\
\text { Emissions }\end{array}$} & \multicolumn{2}{|c|}{$\begin{array}{c}\text { Emissions from Main } \\
\text { Engine, ton.y }\end{array}$} \\
\cline { 2 - 3 } & Cruising & Manoeuvring \\
\hline $\mathrm{NO}_{\mathrm{x}}$ & 295 & 177 \\
\hline $\mathrm{SO}_{2}$ & 200 & 166 \\
\hline $\mathrm{CO}_{2}$ & 11811 & 9744.5 \\
\hline $\mathrm{VOC}$ & 11 & 25 \\
\hline $\mathrm{PM}$ & 30 & 34 \\
\hline $\mathrm{CO}$ & 10 & 8 \\
\hline
\end{tabular}

\begin{tabular}{|c|c|c|}
\hline $\begin{array}{c}\text { Mersin Port } \\
\text { Emissions }\end{array}$ & \multicolumn{2}{|c|}{$\begin{array}{c}\text { Emissions from Main } \\
\text { Engine, ton.y }\end{array}$} \\
\cline { 2 - 3 } & Cruising & Manoeuvring \\
\hline $\mathrm{NO}_{\mathrm{x}}$ & 667 & 400 \\
\hline $\mathrm{SO}_{2}$ & 461 & 382 \\
\hline $\mathrm{CO}_{2}$ & 27231 & 22467 \\
\hline $\mathrm{VOC}$ & 26 & 58 \\
\hline $\mathrm{PM}$ & 70 & 78 \\
\hline $\mathrm{CO}$ & 23.5 & 18 \\
\hline
\end{tabular}

\section{Emissions from the auxiliary engine of ships}

Between 01.09.2017 - 01.09.2018, the emissions of $\mathrm{NO}_{x}, \mathrm{SO}_{2}, \mathrm{CO}_{2}, \mathrm{VOC}, \mathrm{PM}$ and $\mathrm{CO}$ from the main engine were calculated with the 2068 movements of 776 different ships arriving to Izmir Port and 4215 movements of 1202 different ships arriving to Mersin Port. Exhaust gas emissions from each ship's auxiliary engine are calculated using the web-based emission calculation software [1][2] and are shown in Table 11 according to ship operation modes. When the average hotelling time and auxiliary engine powers are examined, it is found that the vessels staying in Mersin Port are longer in the harbor and the auxiliary generator powers are higher. Therefore, emissions from auxiliary machinery are higher in Mersin Port.

Table 11. Emissions from the auxiliary engine of ships in İzmir \& Mersin Port

\begin{tabular}{|c|c|c|c|}
\hline \multirow{2}{*}{$\begin{array}{c}\text { İzmir } \\
\text { Port } \\
\text { Emissions }\end{array}$} & \multicolumn{3}{|c|}{ Emissions from Auxiliary Engines, ton. $\mathbf{y}^{-1}$} \\
\cline { 2 - 4 } & At Sea & Manoeuvring & Hotelling \\
\hline $\mathrm{NO}_{\mathrm{X}}$ & 21 & 67 & 340 \\
\hline $\mathrm{SO}_{2}$ & 11 & 35 & 177 \\
\hline $\mathrm{CO}_{2}$ & 1173 & 3753 & 18839 \\
\hline $\mathrm{VOC}$ & 0.7 & 2 & 11 \\
\hline $\mathrm{PM}$ & 0.7 & 2 & 11 \\
\hline $\mathrm{CO}$ & 0.9 & 3 & 15 \\
\hline
\end{tabular}

\begin{tabular}{|c|c|c|c|}
\hline \multirow{2}{*}{$\begin{array}{c}\text { Mersin } \\
\text { Port } \\
\text { Emissions }\end{array}$} & \multicolumn{3}{|c|}{ Emissions from Auxiliary Engines, ton. $^{\mathbf{1}^{\mathbf{1}}}$} \\
\cline { 2 - 4 } & At Sea & Manoeuvring & Hotelling \\
\hline $\mathrm{NO}_{\mathrm{x}}$ & 50 & 160 & 721 \\
\hline $\mathrm{SO}_{2}$ & 27 & 86 & 383 \\
\hline $\mathrm{CO}_{2}$ & 2861 & 9156 & 40615 \\
\hline $\mathrm{VOC}$ & 2 & 5 & 23.5 \\
\hline $\mathrm{PM}$ & 2 & 5 & 23.5 \\
\hline $\mathrm{CO}$ & 2 & 7 & 32 \\
\hline
\end{tabular}

\section{Emissions according to the ship types}

The emissions of $\mathrm{NO}_{\mathrm{x}}, \mathrm{SO}_{2}, \mathrm{CO}_{2}$, VOC, $\mathrm{PM}$ and $\mathrm{CO}$ for 8 different types of ships are shown in Table 12 and Table 13. As can be seen from the tables, the emission values from container ships are considerably higher than the other types of vessels in the measured date range. Emitted emissions were mostly from container ships. General cargo, which is the most ship type arriving to the ports, is lower than the containers because the average main engine and generator power is much lower on general cargo ships. 
Journal of Thermal Engineering, Research Article, Vol. 5, No. 6, Special Issue 10, pp. 184-195, December, 2019

Table 12. Emissions according to the ship types in Izmir Port

\begin{tabular}{|c|c|c|c|c|c|c|c|c|}
\hline Ship Type & $\begin{array}{c}\text { CONTAINER } \\
\text { SHIP }\end{array}$ & $\begin{array}{c}\text { GENERAL } \\
\text { CARGO }\end{array}$ & $\begin{array}{c}\text { LPG } \\
\text { TANKER }\end{array}$ & $\begin{array}{c}\text { OIL } \\
\text { PRODUCTS } \\
\text { TANKER }\end{array}$ & $\begin{array}{c}\text { RORO / } \\
\text { PASSENGER } \\
\text { SHIP }\end{array}$ & $\begin{array}{c}\text { OIL } \\
\text { CHEMICAL } \\
\text { TANKER }\end{array}$ & $\begin{array}{c}\text { SALVAGE } \\
\text { RESCUE } \\
\text { VESSEL }\end{array}$ & $\begin{array}{c}\text { RORO } \\
\text { CARGO } \\
\text { SHIP }\end{array}$ \\
\hline Number & 144 & 509 & 31 & 13 & 4 & 21 & 4 & 50 \\
\hline Movement & 816 & 899 & 37 & 80 & 28 & 33 & 17 & 158 \\
\hline NO$_{\mathbf{x}}$ & 527.37 & 202.72 & 10.97 & 3.80 & 19.68 & 8.48 & 3.78 & 123.93 \\
\hline $\mathbf{S O}_{2}$ & 354.40 & 125.70 & 6.97 & 2.45 & 13.57 & 4.97 & 2.96 & 78.74 \\
\hline $\mathbf{C O}_{2}$ & 26353.91 & 10933.46 & 622.54 & 213.38 & 1027.87 & 463.96 & 202.11 & 5502.86 \\
\hline VOC & 30.86 & 9.18 & 0.51 & 0.15 & 1.15 & 0.35 & 0.22 & 7.27 \\
\hline PM & 49.41 & 12.47 & 0.68 & 0.22 & 1.81 & 0.44 & 0.33 & 12.15 \\
\hline $\mathbf{C O}$ & 21.28 & 8.61 & 0.49 & 0.17 & 0.83 & 0.37 & 0.16 & 4.49 \\
\hline
\end{tabular}

Table 13. Emissions according to the ship types in Mersin Port

\begin{tabular}{|c|c|c|c|c|c|c|c|c|}
\hline Ship Type & $\begin{array}{l}\text { CONTAINER } \\
\text { SHIP }\end{array}$ & $\begin{array}{c}\text { GENERAL } \\
\text { CARGO }\end{array}$ & $\begin{array}{c}\text { LPG } \\
\text { TANKER }\end{array}$ & $\begin{array}{c}\text { OIL } \\
\text { PRODUCTS } \\
\text { TANKER }\end{array}$ & \begin{tabular}{c|} 
RORO / \\
PASSENGER \\
SHIP \\
\end{tabular} & $\begin{array}{c}\text { OIL } \\
\text { CHEMICAL } \\
\text { TANKER }\end{array}$ & $\begin{array}{c}\text { SALVAGE } \\
\text { RESCUE } \\
\text { VESSEL }\end{array}$ & $\begin{array}{c}\text { RORO } \\
\text { CARGO } \\
\text { SHIP }\end{array}$ \\
\hline Number & 290 & 689 & 82 & 27 & 45 & 6 & 57 & 6 \\
\hline Movement & 1604 & 1147 & 267 & 121 & 491 & 41 & 10 & 534 \\
\hline NO $_{x}$ & 1298.14 & 339.72 & 89.58 & 35.85 & 71.33 & 12.80 & 0.49 & 149.66 \\
\hline $\mathrm{SO}_{2}$ & 902.01 & 195.19 & 58.60 & 23.15 & 53.12 & 8.20 & 0.34 & 98.76 \\
\hline $\mathrm{CO}_{2}$ & 65126.34 & 17702.68 & 5025.58 & 1991.73 & 3770.95 & 708.78 & 28.85 & 7975.58 \\
\hline VOC & 81.11 & 13.93 & 4.48 & 1.79 & 3.91 & 0.62 & 0.02 & 7.94 \\
\hline $\mathbf{P M}$ & 132.97 & 18.20 & 6.32 & 2.56 & 5.78 & 0.86 & 0.03 & 11.85 \\
\hline $\mathrm{CO}$ & 52.92 & 13.94 & 3.99 & 1.59 & 2.91 & 0.56 & 0.02 & 6.36 \\
\hline
\end{tabular}

\section{$\mathrm{CO}_{2}$ Emissions according to the ship flags}

As a result of the $\mathrm{CO}_{2}$ emission calculation, the flags in the first three places in the unit $\mathrm{CO}_{2}$ emission rankings are Liberia, Marshall Islands and Malta. As shown in Table 14, the number of arrivals of these flagged ships is not in the top three. Therefore, flags such are Liberia, Marshall Islands and Malta should pay more attention to exhaust emissions.

Table 14. Total and unit $\mathrm{CO}_{2}$ emissions according to the ship flags in Izmir \& Mersin Ports

\begin{tabular}{|c|c|c|c|}
\hline Flags & Movement & $\mathbf{C O}_{2}\left(\right.$ ton. $\left.^{-\mathbf{1}}\right)$ & $\mathbf{C O}_{2} /$ Arrivals $_{(\text {ton. }} \mathbf{y}^{\mathbf{1}}$ ) \\
\hline LIBERIA & 556 & 23824 & 43 \\
\hline MARSHALL ISL. & 276 & 9550 & 35 \\
\hline MALTA & 522 & 17020 & 33 \\
\hline PORTUGAL & 145 & 4700 & 32 \\
\hline ITALY & 143 & 4317 & 30 \\
\hline PANAMA & 606 & 17573 & 29 \\
\hline TURKEY & 1524 & 24132 & 16 \\
\hline TOGO & 138 & 1487 & 11 \\
\hline RUSSIA & 151 & 1368 & 9 \\
\hline CYPRUS (TRNC) & 613 & 3155 & 5 \\
\hline
\end{tabular}

\section{Total amounts of ship emissions ports (in ton. $\mathbf{y}^{-1}$ ), in different studies}

Total amounts of ship emissions ports $\left(\mathrm{NO}_{\mathrm{x}}, \mathrm{SO}_{2}, \mathrm{CO}_{2}, \mathrm{VOC}, \mathrm{PM}\right.$ and $\left.\mathrm{CO}\right)$ with number of ship calls and inventory year in different studies are shown in Table 15. 
Journal of Thermal Engineering, Research Article, Vol. 5, No. 6, Special Issue 10, pp. 184-195, December, 2019

Table 15. Total amounts of ship emissions ports (in ton y-1) in different studies

\begin{tabular}{|c|c|c|c|c|c|c|c|c|c|}
\hline Port & Year & $\begin{array}{c}\text { Ship } \\
\text { Calls }\end{array}$ & NOX & SO2 & CO & CO2 & VOC & PM & Study \\
\hline İzmir & 2017 & 2068 & 901 & 590 & 36 & 45320 & 50 & 78 & $\begin{array}{c}\text { This } \\
\text { Study }\end{array}$ \\
\hline Mersin & 2017 & 4215 & 1998 & 1339 & 82 & 102330 & 114 & 179 & $\begin{array}{c}\text { This } \\
\text { Study }\end{array}$ \\
\hline İzmir & 2007 & 2806 & 1882 & 1709 & - & 100590 & - & 210.5 & {$[26]$} \\
\hline Ambarlı & 2005 & 5432 & 845 & 242 & 2127 & 78590 & 504 & 36 & {$[27]$} \\
\hline Oakland & 2012 & 1916 & 2484 & 1413 & - & - & - & 219.5 & {$[28]$} \\
\hline Las Palmas & 2011 & 3183 & 4237 & 1420 & 497 & 208697 & - & 338 & {$[29]$} \\
\hline
\end{tabular}

When compared with other studies, although the ship calls decreased by $37 \%$ in İzmir port, $\mathrm{NO}_{\mathrm{x}}, \mathrm{CO}_{2}$ and $\mathrm{SO}_{\mathrm{x}}$ emissions decreased by $50-65 \%$. It has been observed that emissions have decreased considerably after the implementation of international rules. When Oakland port 2012 data and İzmir port 2017 data are compared, it is observed that although the number of ship movements is approximately the same, the calculated emissions of the Oakland port are more than twice the Izmir port emissions. In the comparison of Mersin and Las Palmas ports, although the number of ships arriving to Mersin port is more than $30 \%, \mathrm{SO}_{2}$ emissions of Las Palmas port are close to each other and $\mathrm{NO}_{\mathrm{x}}$ and $\mathrm{CO}_{2}$ emissions are nearly doubled. By updating the emission calculations of these ports, new comparisons will be made more clearly.

\section{CONCLUSION}

In this study, ship movements of İzmir and Mersin ports, which are one of the biggest ports of Turkey, were monitored between September 2017 and September 2018. $\mathrm{NO}_{x}, \mathrm{CO}_{2}, \mathrm{SO}_{2}$, VOC, $\mathrm{CO}$ and PM emissions of 2068 movement of 776 different ships in İzmir port and 4215 movement of 1202 different ships in Mersin port are calculated in different operation modes (cruising, manoeuvring and hotelling) with the web based emission calculation software developed by the methods available in the literature. As a result of the calculations, total $\mathrm{NO}_{x}, \mathrm{SO}_{2}, \mathrm{CO}_{2}$, VOC, $\mathrm{PM}$ and $\mathrm{CO}$ emissions of İzmir Port are calculated as respectively 900 tons / year, 589 tons / year, 45320.5 tons / year, 49.7 tons / year, 77.7 tons / year and 36.9 tons / year. Total $\mathrm{NO}_{\mathrm{x}}, \mathrm{SO}_{2}, \mathrm{CO}_{2}$, VOC, PM and CO emissions of Mersin Port are calculated as respectively 1998 tons / year, 1339 tons / year, 102330 tons / year, 114.5 tons / year, 178.5 tons / year and 82,5 tons / year. $\mathrm{NO}_{\mathrm{x}}$ emission values were observed to be high in both ports due to the construction year average of the ships arriving to İzmir and Mersin ports during 1998 and 1996 respectively. This can be attributed to the high $\mathrm{NO}_{\mathrm{x}}$ emission factors emitted from ships built in and before 2000 and 2011 according to the International Maritime Organization rules.

As a result; both harbor in Turkey's importance with the logistics are among the largest ports. Considering the increase in port capacity over the years and its proximity to the city center as a location, it increases the effects of ship-based exhaust gas emissions on human health and the environment. From this point of view, when determining the port areas to be built in the future, attention should be paid to their impact on human health and the environment. In addition, the technologies used during loading and unloading should be replaced by innovative systems in order to shorten the hotelling period in the port.

In the future studies, starting from high-workload ports in Turkey, "port emissions inventory of Turkey" must be created. In addition, emission factors studies for ports should be carried out with experimental studies and emission measurements on the ship. As a result of Turkey port inventory to be issued, some sanctions may be applied locally in the country within the scope of emission prevention measures. Due to the type of fuel that directly affects $\mathrm{SO}_{x}$ emissions, the use of low-sulfur fuel by vessels not only at ports but also during cruising will reduce $\mathrm{SO}_{\mathrm{x}}$ emissions globally. Therefore, ships may be required to use low-sulfur fuel or exhaust gas scrubber technology to reduce $\mathrm{SO}_{x}$ released into the air. Exhaust Gas Recirculation (EGR) or Selective Catalytic Reduction (SCR) methods can be used to reduce $\mathrm{NO}_{\mathrm{x}}$ emissions. In order to reduce the emissions of $\mathrm{CO}_{2}$ emitted, the fuel consumption of the ships should be reduced, and the maritime companies should pay more attention to energy efficiency. 


\section{REFERENCES}

[1] F. Alarçin, G. Kökkülünk, and K. Ünlügençoğlu, "Estimation of Shipping Emissions via Novel Developed Data Collecting and Calculation Software: A Case Study for the Region of Ambarli Port," Int. J. Glob. Warm., vol. 19, p. 1, Jan. 2019.

[2] K. Ünlügençoğlu, "Investigation of exhaust emissions from ships with different methods," Yıldız Technical university, 2018.

[3] R. A. O. Nunes, M. C. M. Alvim-Ferraz, F. G. Martins, and S. I. V. Sousa, "Assessment of shipping emissions on four ports of Portugal," Environ. Pollut., vol. 231, pp. 1370-1379, 2017.

[4] C. Trozzi, "Emission estimate methodology for maritime navigation," p. 6, 2010.

[5] N. Robinson, "European Commission Quantification of emissions from ships associated with ship movements between ports in the European Community European Commission Quantification of emissions from ships associated with ship movements between ports in the European Commu," no. July, 2002.

[6] E. Tzannatos, "Ship emissions and their externalities for the port of Piraeus - Greece," Atmos. Environ., vol. 44, no. 3, pp. 400-407, 2010.

[7] V. Knežević, R. Radonja, and Č. Dundović, "Emission inventory of marine traffic for the port of zadar," Pomorstvo, vol. 32, no. 2, pp. 239-244, 2018.

[8] J. Coello, I. Williams, D. A. Hudson, and S. Kemp, "An AIS-based approach to calculate atmospheric emissions from the UK fishing fleet," Atmos. Environ., vol. 114, pp. 1-7, 2015.

[9] D. O. Olukanni and C. O. Esu, "Estimating greenhouse gas emissions from port vessel operations at the Lagos and Tin Can ports of Nigeria," Cogent Eng., vol. 5, no. 1, pp. 1-9, 2018.

[10] Y. T. Chang, Y. Song, and Y. Roh, "Assessing greenhouse gas emissions from port vessel operations at the Port of Incheon,” Transp. Res. Part D Transp. Environ., vol. 25, pp. 1-4, 2013.

[11] F. Ledoux, C. Roche, F. Cazier, C. Beaugard, and D. Courcot, "Influence of ship emissions on NOx, SO2, O3 and PM concentrations in a North-Sea harbor in France," J. Environ. Sci. (China), vol. 71, no. x, pp. 56-66, 2018.

[12] T. Chu-Van et al., "On-board measurements of particle and gaseous emissions from a large cargo vessel at different operating conditions," Environ. Pollut., vol. 237, pp. 832-841, 2018.

[13] J. Cheng and H. Li, "Analysis of Environmental Benefits of Shore Power for Preventing and Controlling Air Pollution Caused by Vessels at Berth," E3S Web Conf., vol. 53, no. 2018, 2018.

[14] X. Sun, Z. Tian, R. Malekian, and Z. Li, "Estimation of vessel emissions inventory in Qingdao port based on big data analysis," Symmetry (Basel)., vol. 10, no. 10, pp. 1-11, 2018.

[15] D. Chen et al., "Estimating ship emissions based on AIS data for port of Tianjin, China," Atmos. Environ., vol. 145, pp. 10-18, 2016.

[16] C. Deniz and Y. Durmuşoğlu, "Estimating shipping emissions in the region of the Sea of Marmara, Turkey," Sci. Total Environ., vol. 390, no. 1, pp. 255-261, 2008.

[17] C. Schembari et al., "Impact of a European directive on ship emissions on air quality in Mediterranean harbours," Atmos. Environ., vol. 61, pp. 661-669, 2012.

[18] M. Zetterdahl, J. Moldanová, X. Pei, R. K. Pathak, and B. Demirdjian, "Impact of the $0.1 \%$ fuel sulfur content limit in SECA on particle and gaseous emissions from marine vessels," Atmos. Environ., vol. 145, pp. 338-345, 2016.

[19] M. Tichavska, B. Tovar, D. Gritsenko, L. Johansson, and J. P. Jalkanen, "Air emissions from ships in port: Does regulation make a difference?," Transp. Policy, no. March, 2015.

[20] A. Ortega Piris, E. Díaz-Ruiz-Navamuel, C. A. Pérez-Labajos, and J. Oria Chaveli, "Reduction of CO2 emissions with automatic mooring systems. The case of the port of Santander," Atmos. Pollut. Res., vol. 9, no. 1, pp. 76-83, 2018.

[21] ENTEC, "Defra UK Ship Emissions Inventory, Final Report," no. November, 2010.

[22] L. Bilgili and U. B. Celebi, "Developing a new green ship approach for flue gas emission estimation of bulk carriers," Meas. J. Int. Meas. Confed., vol. 120, no. July, pp. 121-127, 2018.

[23] "Izmir Port." [Online]. Available: http://www.investinizmir.com/upload/Node/27441/files/IZMIR_DENIZYOLU_LOJISTIGI_LIMANLA R.pdf. [Accessed: 16-Sep-2019].

[24] "Mersin Int. Port." [Online]. Available: https://www.mersinport.com.tr. [Accessed: 16-Sep-2019].

[25] C. Wang, J. J. Corbett, and J. Firestone, "Modeling energy use and emissions from North American shipping: Application of the ship traffic, energy, and environment model," Environ. Sci. Technol., vol. 41, no. 9, pp. 3226-3232, 2007.

[26] H. Saracoglu, "Investigation of exhaust gas emissions of ships calling İzmir Port and their environmental impacts," Istanbul Technical University, 2010.

[27] C. Deniz and A. Kilic, "Estimation and Assessment of Shipping Emissions in the Region of Ambarl Port, Turkey,” Environ. Prog. Sustain. Energy, vol. 29, no. 1, pp. 107-115, 2009. 
Journal of Thermal Engineering, Research Article, Vol. 5, No. 6, Special Issue 10, pp. 184-195, December, 2019

[28] Environ International Corporation, "Port of Oakland 2012 Seaport Air Emissions Inventory," 2013.

[29] M. Tichavska and B. Tovar, "Port-city exhaust emission model: An application to cruise and ferry operations in Las Palmas Port,” Transp. Res. Part A Policy Pract., vol. 78, pp. 347-360, 2015. 